\title{
Impacts of Climate Variability on Latin American Small-scale Fisheries
}

\author{
Omar Defeo $^{1,2}$, Mauricio Castrejón $^{3}$, Leonardo Ortega $^{2}$, Angela M. Kuhn $^{4}$, Nicolás L. Gutiérrez $^{5}$ and Juan Carlos Castilla $^{6}$
}

\begin{abstract}
Small-scale fisheries (SSFs) are social-ecological systems that play a critical role in terms of food security and poverty alleviation in Latin America. These fisheries are increasingly threatened by anthropogenic and climatic drivers acting at multiple scales. We review the effects of climate variability on Latin American SSFs, and discuss the combined effects of two additional human drivers: globalization of markets and governance. We show drastic long-term and large-scale effects of climate variability, e.g., sea surface temperature anomalies, wind intensity, sea level, and climatic indices, on SSFs. These variables, acting in concert with economic drivers, have exacerbated stock depletion rates in Latin American SSFs. The impact of these drivers varied according to the life cycle and latitudinal distribution of the target species, the characteristics of the oceanographic systems, and the inherent features of the social systems. Our review highlights the urgent need to improve management and governance systems to promote resilience as a way to cope with the increasing uncertainty about the impacts of climate and globalization of markets on Latin American SSFs.
\end{abstract}

RESUMEN. Las pesquerías artesanales son sistemas sociales-ecológicos que desempeñan un papel clave en términos de seguridad alimentaria y la mitigación de la pobreza en América Latina. Estas pesquerías se encuentran cada vez más amenazadas por las presiones antropogénicas y climáticas que actúan a múltiples escalas temporales y espaciales. En este trabajo se ha evaluado la relación entre la variabilidad climática y los recursos pesqueros como una aproximación para comprender los posibles efectos a corto y largo plazo del cambio climático sobre las pesquerías artesanales en América Latina, teniendo en cuenta el efecto combinado de dos factores de estrés humanos adicionales: la globalización de los mercados y la gobernanza. En base al análisis cuantitativo de las extensas bases de datos utilizadas y empleando el enfoque de casos de estudio, este trabajo demuestra que se están produciendo efectos dramáticos a largo plazo y a gran escala de la variabilidad climática, que actuando de manera concertada con factores bioeconómicos, han exacerbado las tasas de depleción de los stocks en América Latina. En particular, hemos identificado dos principales factores del cambio global: (1) la variabilidad del clima a través de las anomalías de temperatura superficial del mar, de la intensidad del viento, del incremento del nivel del mar y del uso de índices climáticos, y (2) el aumento en los precios unitarios en las pesquerías artesanales que se encuentran altamente integradas en el mercado mundial de productos de la pesca. Los resultados también indican que el impacto de estos factores varía según el ciclo de vida y la distribución latitudinal de las especies objetivo, las características intrínsecas de los sistemas oceanográficos y las particularidades inherentes de los sistemas sociales. Nuestros resultados ponen de manifiesto la necesidad urgente de desarrollar instituciones sólidas, mejores sistemas de gobernanza y regulaciones de gestión eficaces para promover la resiliencia como una manera de hacer frente a la creciente incertidumbre sobre el impacto futuro del cambio climático y la globalización de los mercados internacionales sobre las pesquerías artesanales de América Latina.

Key Words: climate variability; ENSO; global change; Latin America; resilience; small-scale fisheries América Latina, cambio global; ENSO; pesquerías artesanales; resiliencia; variabilidad climática

\section{INTRODUCTION}

Small-scale fisheries (SSFs) are embedded in socialecological systems (SES) that include biophysical and social subsystems operating through interdependent feedback relationships (Ostrom 2009, Perry et al. 2010, Hall 2011). SSFs play critical roles in developing countries, in the context of food security and poverty alleviation (Berkes et al. 2001, Chuenpagdee et al. 2006, Jentoft and Eide 2011), accounting for $90 \%$ of some 120 million direct and indirect fisheries livelihoods that support more than 500 million people (FAO 2012). The resilience of SSFs is frequently low (Pauly 2006, Bueno and Basurto 2009) given their vulnerability to local and global external drivers that affect the resources per se and/or the social structure of the system (Hall 2011, Jentoft and Eide 2011). Indeed, the coastal systems in which SSFs are developed exhibit high climatic and oceanographic variability (Chavez et al. 2003) and are particularly vulnerable to perturbations produced by extreme natural events and climate change trends.

In Latin America, about 2500 small-scale fishing communities and several million people are directly or indirectly engaged in the activity (Defeo and Castilla 2005, Salas et al. 2011). These SSFs are developed in inshore coastal waters, aimed for sale and/or subsistence, by one fisher or a small group of fishers

${ }^{1}$ UNDECIMAR, Facultad de Ciencias, Montevideo, Uruguay, ${ }^{2}$ DINARA, Montevideo, Uruguay, ${ }^{3}$ Interdisciplinary PhD program, Dalhousie University, Halifax, Nova Scotia, Canada, ${ }^{4}$ Department of Oceanography, Dalhousie University, Halifax, Nova Scotia, Canada, ${ }^{5}$ Marine Stewardship Council, London, UK, ${ }^{6}$ Centro de Conservación Marina, ECIM, Las Cruces and Centro de Cambio Global. Universidad Católica de Chile, Santiago, Chile 
that employ different fishing gears to extract a wide diversity of coastal resources (Defeo and Castilla 2005). Management tools and institutional arrangements also differ among fisheries (Begossi 2010, Salas et al. 2011). Latin American SSFs are increasingly threatened by human and climatic drivers acting at multiple temporal and spatial scales, including uncontrolled fishing intensity, interdependencies with industrial fisheries, sea-level rise, hurricanes, and other climatic events (Bovarnick et al. 2010, Defeo and Castilla 2012). Consequently, SSFs are being degraded rapidly, suffering underemployment, income reduction, and reduced access to marine food (Defeo and Castilla 2012).

As the number and magnitude of global change drivers increase over time, there is an urgent need to understand how the performance of SSFs is being affected by climate variability and human drivers. Even though climate change is currently receiving most attention, others are acting simultaneously, and their combined effects should be analyzed (Perry et al. 2010, McCay et al. 2011). In this paper we review the effects of climate variability on SSFs in Latin America, considering also the combined effects of two additional human drivers: globalization of markets and governance. To show potential combined effects of these drivers, emphasis is placed on case studies for which long-term information is available for both the biophysical and social subsystems of SSF.

\section{EFFECTS OF CLIMATE VARIABILITY ON LATIN AMERICAN SSFs}

\section{Shellfisheries}

Sedentary and sessile shellfishes are susceptible to rapid environmental changes. Owing to their strict association with sedimentological variables (Defeo and McLachlan 2011), several shellfishes are unable to adapt their distribution to compensate for warming temperatures and other climate change consequences, such as ocean acidification and sea level rise (Defeo et al. 2009, Heath et al. 2012, Narita et al. 2012). These drivers could affect habitats and biophysical processes and thus could alter shellfish demography, dispersal patterns, life history traits, and interaction strength with other species (Stenseth et al. 2002, Rouyer et al. 2008, Mellin et al. 2012). Potential impacts resulting from climatic drivers can be related to the Atlantic Multidecadal Oscillation (AMO), the Pacific Decadal Oscillation (PDO), and the El Niño Southern Oscillation (ENSO), which account for major variations in weather and climate around the world (Stenseth et al. 2002). This variability influences currents and water mass properties (Delworth and Mann 2000) and affects ecosystems, including species targeted by SSFs (Montecino and Lange 2009).

Changes in climatic drivers might directly favor certain species over others, based on their latitudinal distribution and the oceanographic features of the area (Badjeck et al. 2009). Indeed, a recent evaluation of the surf clam (Mesodesma donacium) in the Pacific (distribution range from $5^{\circ} \mathrm{S}$ to $42^{\circ}$
S) suggested that warm ENSO (El Niño) events negatively affected landings in Peru and northern Chile (Fig. 1A), but favored landings in southern Chile (southernmost edge of the species distribution), showing a positive correlation with increasing sea surface temperature anomalies (SSTA; Ortega et al. 2012). Particularly in Peruvian beaches, the strong 1982/1983 and 1997/1998 El Niño events caused mass mortalities of surf clam (Arntz et al. 1987). The same differential response to extreme events was observed for the artisanally harvested Peruvian bay scallop (Argopecten purpuratus): in the north of Peru, strong El Niño events drastically increased floods and river discharges, causing a decrease in scallop biomass, whereas increasing temperatures in the south produced a positive effect on stock size (Badjeck et al. 2009). During the 1997/1998 El Niño event, Independence Bay $\left(14^{\circ} \mathrm{S}\right.$, Peru) showed a $10^{\circ} \mathrm{C}$ increase in sea surface temperature (SST), high oxygen concentrations, and diminished phytoplankton concentrations. Many benthic species were affected, e.g., macroalgae, portunid crabs, and polychaetes, whereas others benefited, e.g., scallop, sea stars, and sea urchins, particularly A. purpuratus, whose biomass increased 50-fold (Taylor et al. 2008). Castilla and Camus (1992) also showed declining shellfish landings in northern Chile after the 1982/1983 El Niño, in concurrence with high exploitation levels of the gastropod Concholepas concholepas and the kelp Lessonia nigrescens. Nevertheless, Defeo and Castilla (1998) described a dramatic increase in Octopus mimus landings and density, by a factor of 100 , in northern Chile, during and after the 1982/1983 El Niño. Increasing SST enhanced recruitment and availability of octopus prey items (Castilla and Camus 1992).

In the southwestern Atlantic Ocean, long-term trends in abundance of the yellow clam (Mesodesma mactroides) were negatively affected by a combined effect of increasing SSTA and fishing intensity (Ortega et al. 2012). SSTA was positively correlated with AMO variations and both indices were inversely correlated with yellow clam abundance (Fig. 1C), meaning higher abundance during cold periods. The AMO shifted after 1994 from a cold to a warm period (Goldenberg et al. 2001), probably triggering yellow clam mass mortalities. Indeed, mass mortalities that decimated populations of $M$. mactroides (Atlantic) and M. donacium (Pacific) along their geographic ranges had been associated with increasing temperatures (Arntz et al. 1987, Fiori et al. 2004, Riascos et al. 2009). In M. mactroides, mass mortalities sequentially has occurred in a north-south direction since 1993 (southern Brazil) to 2002 (Argentina; Fig. 1D). These mortalities were mainly observed between late spring and early summer, when these cold-water clams are more sensitive to diseases (Fiori et al. 2004, Herrmann et al. 2011). The systematic increase in SSTA, associated with a southward migration of a critical warm isotherm, has exacerbated the negative influence of warm waters. 
Fig. 1. (A) Long-term variations in the surf clam (Mesodesma donacium) landings and Pacific Decadal Oscillation (PDO) index for northern Chile. The shaded bar indicates a climate shift that occurred in 1977, according to Fiedler (2002) and Chavez et al. (2003). See the drastic decline in landings and PDO during the 1997/1998 El Niño. (B) Long-term trends in landings and unit prices for the surf clam fishery in Chile. (C) Long-term trends in abundance of the yellow clam (Mesodesma mactroides) in a Uruguayan beach and Atlantic Multidecadal Oscillation (AMO) index. See the match in the regime shift from a cold to a warm period that took place between 1994 and 1995 (Goldenberg et al. 2001) and the occurrence of mass mortalities. (D) At a large scale, these mortalities sequentially occurred in a north-south direction from 1993 (southern Brazil) to 2002 (Argentina). For illustration purposes, sea surface temperature for the year 2006 is shown. Data source: Ortega et al. (2012).

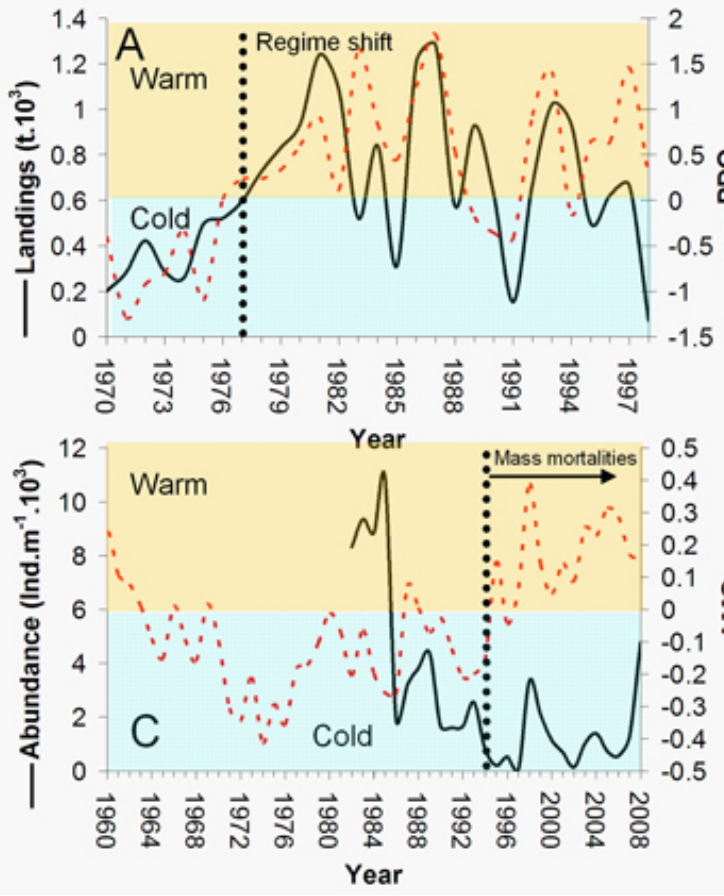

The effects of climate variability, in addition to unregulated fishing, have swamped management measures directed to rebuild stocks. In Peru, adverse climate effects on clams were exacerbated by unsustainable harvest levels and weak governance, i.e., open access. After the 1997/1998 El Niño event, the surf clam almost disappeared and the fishery was closed in 1999. The species has not recovered, and the fishery is still closed (Ortega et al. 2012). On Atlantic coasts, mass mortalities have determined fishery closures for almost two decades, without evidence of recovery of the harvestable stock (Fiori and Defeo 2006). The lack of response of stocks to longterm fishery closures suggests that these systems exceeded critical thresholds or tipping points (Scheffer et al. 2009), shifting from one state to another that included drastic variations in community composition. Indeed, Mesodesma clams, formerly dominant in terms of biomass, were replaced by their subordinate competitors for food and space, the bivalves Donax spp and sand crabs Emerita spp in Pacific
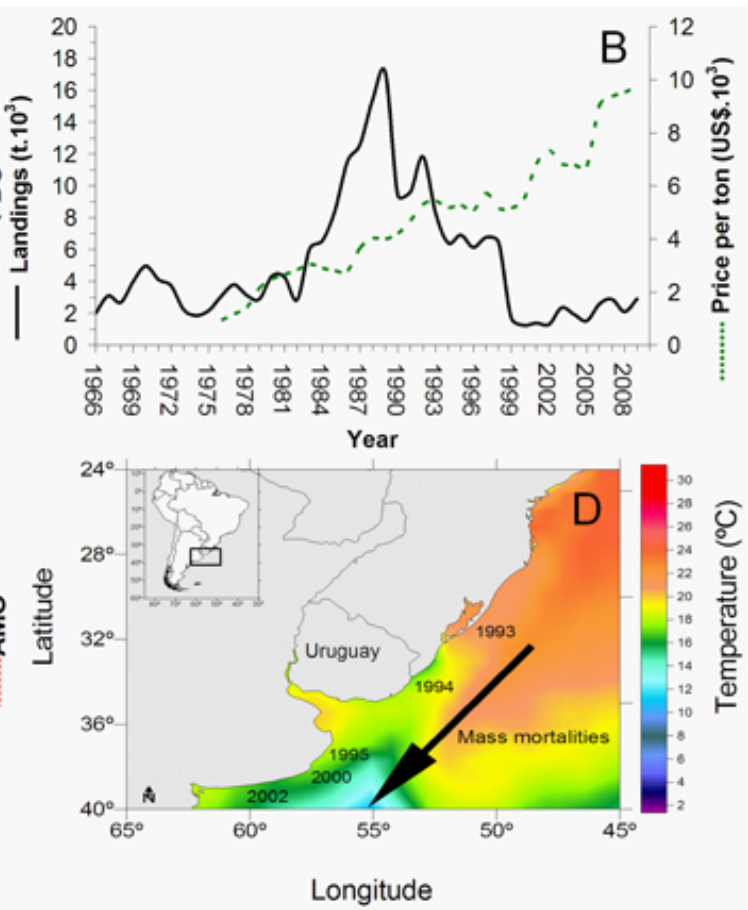

(Arntz et al. 1987) and Atlantic (Defeo 2003) sandy beach ecosystems. Mass mortalities were also observed in intertidal and shallow subtidal shellfish, e.g., oysters, pen shells, clams, spiny lobsters, of the Gulf of California, where coastal fisheries comprise some 70 species, for an annual catch of nearly 200,000 tons (Lluch-Cota et al. 2007). ENSO events (El Niño and La Niña) and associated climate-driven hypoxia affected the abundance and distribution of these resources in a differential way (Micheli et al. 2012).

The sustained increase in SST could accelerate sea level rise rates, inundating many low-lying coastal and intertidal areas. In addition, changes in the global heat balance could lead to extreme weather events, including more frequent and severe storms (IPCC 2007). These events could affect coastal ecosystems, resulting in coastal squeeze, which leaves ecosystems trapped between erosion and rising sea level on the wet side and encroaching development from expanding human populations on land (Defeo et al. 2009, Revell et al. 
2011). This could affect the quality and availability of species' habitats targeted by SSFs and therefore the abundance of, and accessibility to, fish stocks targeted by fishing-dependent coastal communities. An example is provided by a $29-y$ study for the yellow clam M. mactroides, which is harvested by handpicking methods in the intertidal zone. There is a strong correlation between SSTA and wind speed anomalies (Ortega et al. 2013), which reach their highest values toward the end of the study period (Fig. 2A). The increasing wind speed anomalies are associated with faster and more frequent onshore winds, which explain the linear increasing pattern in swash width through time (Fig. 2B). These changes in the intertidal habitat could negatively affect clams' recruitment and survival, as well as the accessibility by fishers to the resource. Thus, economic income from fishing could be diminished because of a decrease in the number of fishable days through time (Fig. 2C). Consequently, unemployment and disruption and relocation of fishing villages could be generated. This hypothesis should be subject to future research.

Humans are a major force in global change, shaping ecosystem dynamics from local environments to the biosphere as a whole (Folke et al. 2011). Thus, managing SSFs should take into account the interactions between drivers affecting biophysical and social subsystems (Perry et al. 2011). In this context, the combination of weak governance, globalization of markets, fishing pressure, and climate change has exacerbated resource depletion in Latin American shellfisheries, impinging on resource sustainability and the well-being of SSF communities (Defeo and Castilla 2012). Notably, shellfish unit price significantly increased since the early 1980 s, particularly as a result of (Defeo and Castilla 2005, 2012, Ortega et al. 2012): (1) incentives generated by market globalization and an exponential increase in demand, mostly coming from developed countries where shellfish have been previously overexploited; (2) weak and unstable governance regimes, which lack structures and processes needed to shape collective actions leading to sharing power and making decisions; and (3) uncontrolled and unsustainable harvest levels. Indeed, deficit of supply relative to demand, coupled with low harvesting costs and open access regimes, pushed the price up (see Fig. 1B and Defeo and Castilla 2012) and triggered an exponential increase in fishing effort, even under diminishing catch rates, which have driven several shellfishes artisanally harvested in Latin America to levels close to extinction, i.e., the anthropogenic Allee effect (see Courchamp et al. 2006 for concept development). Depletion patterns of high-value species caused a shift of fishing effort onto formerly low-value species, causing a sequential depletion of shellfisheries during the last three decades. Open access systems do not work, and a way to approach this problem is by rewarding local management with formal cross-scale governance recognition and support. Unfortunately, Latin American regulatory
Fig. 2. (A) Long-term variations in sea surface temperature anomalies and wind speed anomalies for the southwestern Atlantic Ocean. Values corresponding to the beginning and end of the time series are highlighted. (B) Long-term linear increase in the swash width at Barra del Chuy beach, Uruguay, where the yellow clam (Mesodesma mactroides) is harvested. (C) Variations in the number of fishable days for January and February (austral summer), which constitute the months with the highest fishing activity. $* * * \mathrm{P}<0.001$. A and B: data source from Ortega et al. (2013). C: original information.
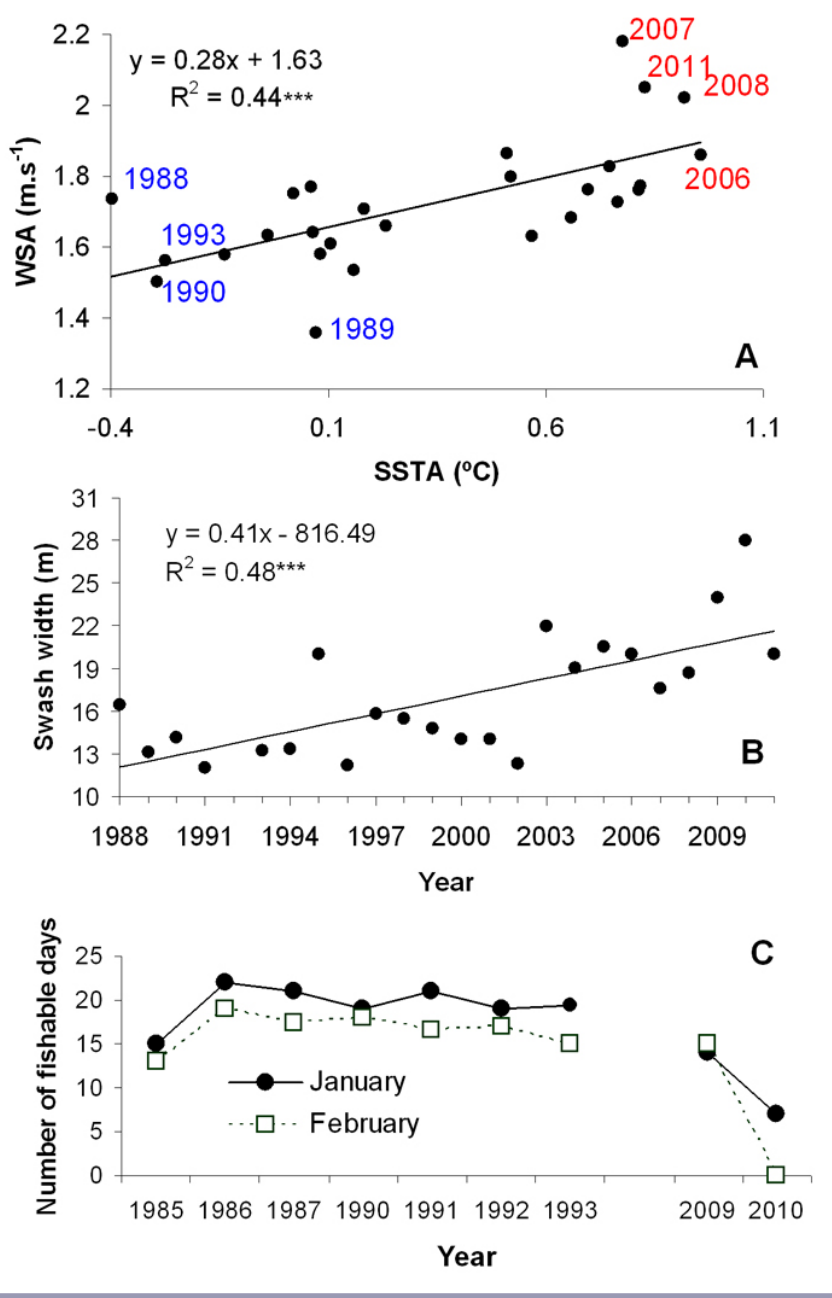

agencies tend to respond late to the problems at hand, once they are more difficult or even impossible to resolve. This situation commonly occurs because many countries lack longterm strategic planning and accountability mechanisms (reviewed in Defeo and Castilla 2012). As SSFs in Latin America tend to be strongly influenced by short-term economic and political interests, they are less resilient and 
more vulnerable to the long-term challenges associated with climate variability.

\section{Negative and positive effects of El Niño: Galápagos as a case study}

The Galápagos Islands, Ecuador, represent a unique place to assess the potential impacts of climate variability on marine species because of their location on the Equatorial Pacific Ocean, the main influence area of ENSO. Long-term analysis indicates that shallow reef habitats across the central Galápagos archipelago experienced major transformations during the 1982/1983 El Niño event (Edgar et al. 2010 and references therein). The removal of large lobsters and fish predators by SSFs probably magnified 1982/1983 El Niño impacts through a cascade of indirect effects involving population expansion of grazing sea urchins. Thus, heavily grazed reefs with crustose coralline algae, "urchin barrens," replaced former macroalgal and coral habitats, resulting in declines in biodiversity (Edgar et al. 2010). Wolff et al. (2012a) evaluated the dynamics of subtidal communities and marine vertebrates during the period 1994-2009, based on a trophic mass balance model of the Bolivar Channel ecosystem, the most productive area of the archipelago. These authors showed that SST increased by $7^{\circ} \mathrm{C}$ during the 1997/1998 El Niño, when phytoplankton concentration decreased by $46 \%$ and $33 \%$, respectively, and the ecosystem size (total energy throughput) was reduced by $70 \%$. This was reflected in the reduction of pelagic and demersal fish, seabirds, reptiles, and marine mammals. Wolff et al. (2012a) suggested that bottomup effects largely control the system during El Niño events.

Not all species are affected negatively by El Niño events. For example, the biomass of spiny lobsters (Panulirus penicillatus and $P$. gracilis) and sea cucumbers (Isostichopus fuscus) increased after the 1997/1998 El Niño. The production (landings) of these two iconic Galápagos shellfisheries could be related to variations in SST in general (Fig. 3A, C), and particularly during El Niño events (Fig. 3B, D). The strongest impact is associated with the 1997/1998 El Niño event, which represents the most intense climatic event recorded in the last 30 years. Two and five years after this event, the spiny lobster and sea cucumber registered maximum historic production levels ( 85 tons of tail and 8.3 million individuals, respectively). The significant linear relationship between the lagged production (catch series linearly detrended from 1994 to 2011 to account for the effect of fishing) and SST explained 36\% and $49 \%$ of the annual production registered for the spiny lobster and sea cucumber fisheries, respectively (Fig. 3B, D).

The high production levels registered for the sea cucumber SSF in 2002 have been the combined result of two main factors (Hearn et al. 2005, Castrejón 2011, Wolff et al. 2012a): (1) a strong recruitment pulse triggered by the 1997/1998 El Niño that led to unusually high stock densities during years 2000
2003; and (2) an increase in fishing effort that resulted from the opening of the sea cucumber artisanal fishery in 1999. Sea cucumber recruits increased in density by a factor of 20 in the west part of the archipelago (Hearn et al. 2005). Such pulse was reflected in the catch composition, where the proportion of juveniles increased from $9 \%$ in 1999 to $56 \%$ in 2002 (Murillo et al. 2002). The same factors, combined with a low predator abundance, e.g., demersal fish, and high prey abundance, e.g., sea urchins, after the 1997/1998 El Niño, could explain the high production of spiny lobsters in 2000 (Bustamante et al. 2002, Hearn and Murillo 2008, Wolff et al. 2012b). However, conclusive scientific evidence is still needed to support this hypothesis. After 1998, warm anomalies associated with ENSO have been mostly confined to the central Pacific Ocean (Lee and McPhaden 2010). Thus, Galápagos experienced an extended cool regime during the last decade, which together with overfishing might be responsible for the low levels of sea cucumber recruitment (Wolff et al. 2012a). The combined effects of poor recruitment and high fishing levels have severely affected this SSF, leading to its closure in 2006, 2009, 2010, and 2012.

\section{Impacts of climate variability in freshwater and estuarine SSFs}

The effects of climate variability in freshwater and estuarine systems will likely result in an increased temperature, decreased dissolved oxygen levels, eutrophication, water level changes, stratification, and salinization (Jeppesen et al. 2012). The response of freshwater fish to warmer waters has been strong and fast in recent decades, including changes in assemblage composition, shifts toward dominance of eurythermal species (Jeppesen et al. 2012), loss of spawning habitats, and changes in spawning and recruitment of fish stocks exploited by SSFs (Ficke et al. 2007). A remarkable interannual variation in abundance and yield of freshwater and coastal lagoon fishes targeted by SSFs has been attributed to ENSO variability (Ficke et al. 2007) and concurrent changes in salinity, as observed in the introduced tilapia Oreochromis niloticus SSF in northern Colombia (Blanco et al. 2007). In this case, favorable climate-hydrological changes during La Niña years 1996, 1999, and 2000, promoted an increase in fishery yields, whereas tilapia disappeared from the coastal lagoon between 2001 and 2005, partially because of salinity concentrations > 10 PSU. River discharge variations associated with climatic signals (ENSO and others) could affect ichthyoplankton retention of the whitemouth croaker (Micropogonias furnieri), the main resource targeted by artisanal and industrial fisheries in the Rio de la Plata estuary. These events could regulate fish recruitment by promoting high (low) recruitment during low (high) discharge periods (Acha et al. 2012).

Nonindigenous species (NIS) are extending their southern range of distribution in Latin America (Orensanz et al. 2002, Castilla and Neill 2009), and their abundance increased 
Fig. 3. Time series and linear regressions between mean annual sea surface temperature (SST in situ, Santa Cruz Island) and lagged annual catch of spiny lobster (Panulirus penicillatus and P. gracilis; A, B) and sea cucumber (Isostichopus fuscus; C, D) in the Galápagos Islands, Ecuador. Catch series from 1995 to 2011 were linearly detrended and the residuals added to the mean, to account for the effect of fishing. Encircled triangles in B and D indicate the positive effect of 1997/1998 El Niño over spiny lobster (2000) and sea cucumber (2002-2003) catches. El Niño and La Niña events were defined based on the Oceanic Niño Index (ONI) estimated by the National Oceanic and Atmospheric Administration (NOAA). **: P < 0.05 ; ***: $\mathrm{P}<0.001$. Catch and SST time series were provided by Galápagos National Park and Charles Darwin Foundation (2012).

-- SST $-0-$ Spiny lobster $-\diamond-$ Sea cucumber
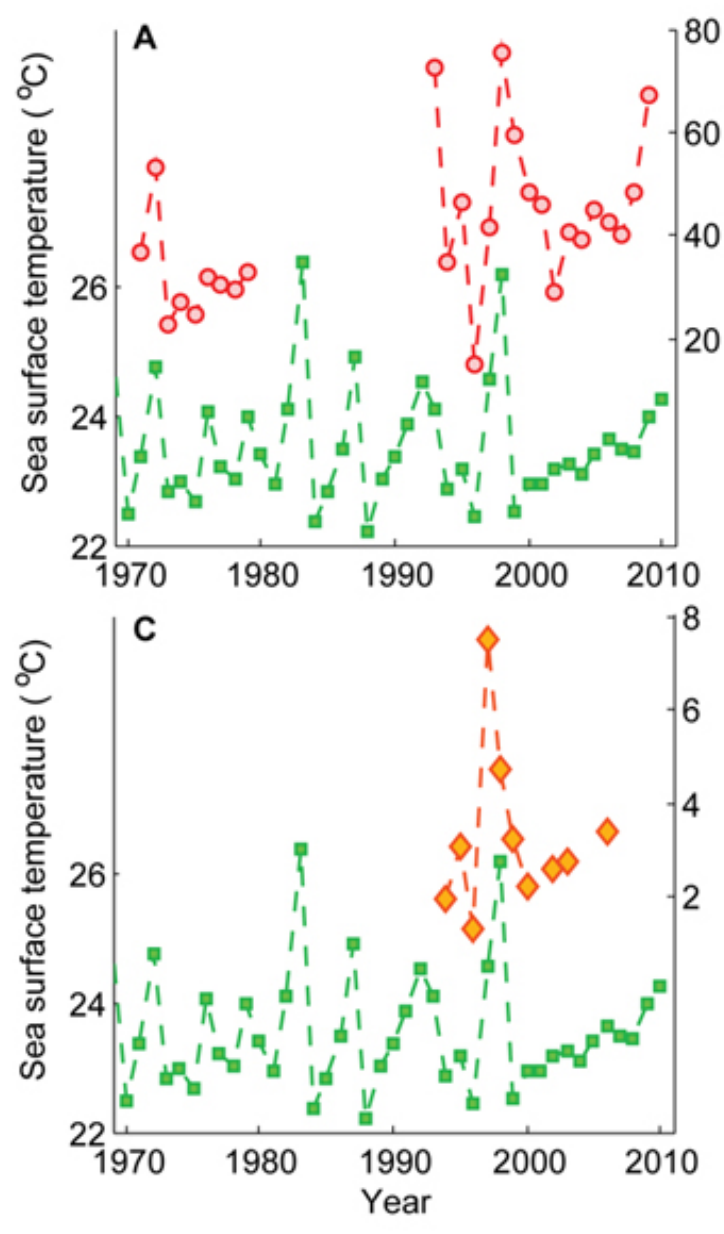

$\Delta$ El Niño $\quad \nabla$ La Niña
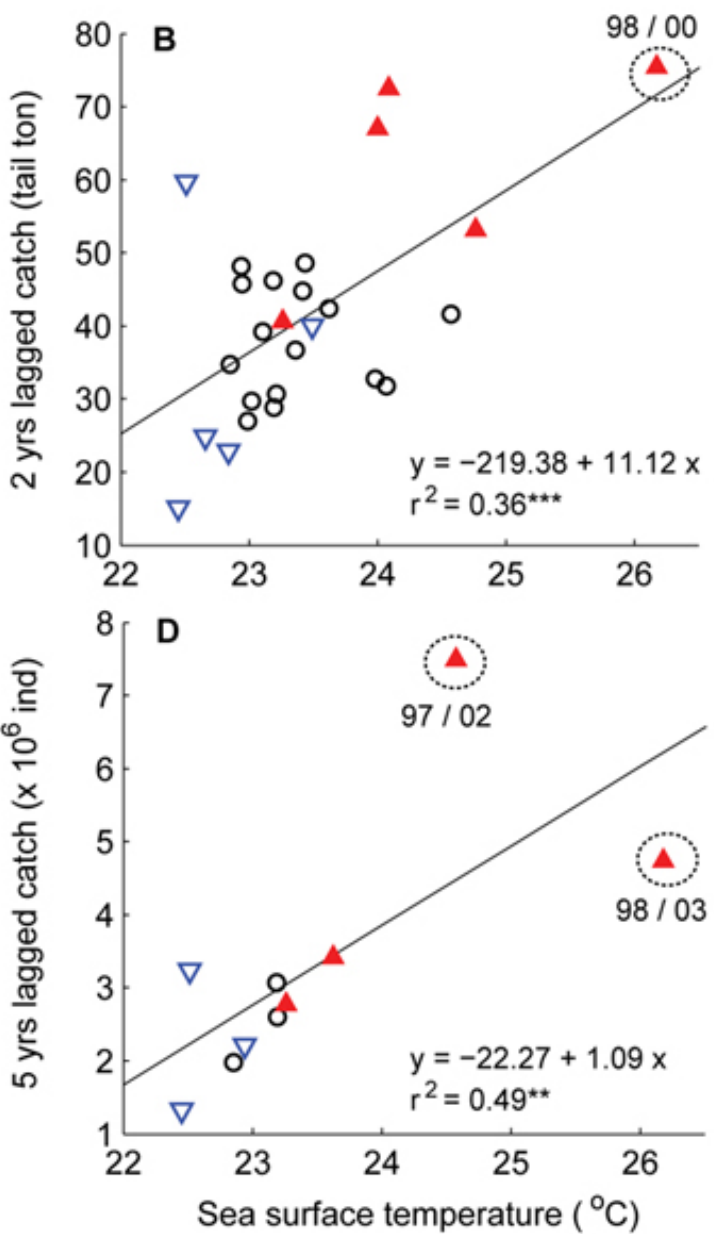

exponentially during the last 20 years, partly because of the combination of rising temperature and strong El Niño events (Castilla et al. 2005). Particularly, NIS invasions have altered community structure and diversity in freshwater and estuarine ecosystems of Latin America, and negatively affected SSFs. For example, the sustained increase of the Asiatic clams (Corbicula fluminea and Limnoperna fortunei) and the invasive whelk (Rapana venosa) in coastal/inshore ecosystems of South America generated drastic ecosystem effects that included the depletion of native species exploited by SSFs, such as the blue mussel (Mytilus edulis platensis; Lercari and Bergamino 2011).

\section{DISCUSSION}

Our review provides growing evidence of long-term and largescale effects of climate variability, and their synergy with bioeconomic drivers, on Latin American SSFs. The impact of different drivers varies according to the life cycle of the species, oceanographic characteristics, and the inherent 
features of the social systems. Interactions between multiple human-induced drivers exacerbated nonlinear responses of ecosystems to climate change and restricted their adaptive capacity (Ling et al. 2009). Our long-term case studies showed that there is not a single response of SSFs to different climatic and human drivers. In some cases the responses were only temporary, e.g., in Galápagos ENSO triggered successful recruitments, but weak governance led to overexploitation in the short term. Therefore, it is difficult to isolate natural and human-induced, e.g., market, factors that jointly alter these SES. Methods directed to quantify the impacts of climate change on marine ecosystems are generally hard to test, partially because of uncertainties about the magnitude of specific impacts on several ecosystem components (Barange et al. 2010, Grafton 2010). It is worth highlighting that our review is focused on Latin American SSFs, but all three drivers analyzed here, i.e., climate variability, weak governance, and market globalization, affect other SSFs, and also industrial fisheries, throughout the world. Given that global fisheries catches have already changed in a manner associated with global warming trends (Cheung et al. 2013), the need to consider environmental conditions when formulating management strategies has acquired more importance than ever. This is particularly relevant for SES threatened by multiple drivers acting in a nonlinear manner through time and space (Perry et al. 2010).

Long-term Latin America shellfish data series reviewed here showed drastic effects of climate variability on SSFs. Most shellfishes are structured as metapopulations defined by a planktonic larvae and a benthic adult phase decoupled in space and time. Large fluctuations in abundance, highly driven by climatic drivers, have led to their description as "resurgent populations" (McLachlan et al. 1996). In addition, most of these stocks appear to be quasi-pulse age-class dominated populations, where contractions/expansions in their geographic range and changes in their population structure vary according to environmental settings, notably SST. Recruitment tends to occur regularly in source areas and to be irregular or spasmodic in sink areas or marginal portions of the habitat, i.e., the habitat favorability hypothesis (Caddy and Defeo 2003). Successful recruitment linked to favorable climate conditions could give rise to a fishery for one, or a very few, age groups occupying areas where the species was not previously abundant. These features of coastal shellfish make them particularly susceptible to the combined effects of fishing and climate fluctuations, going through a "boom and bust" cycle in which landings are initially high in concurrence with successful recruitments, and then decline to low levels when unfavorable climatic situations lead to poor recruitment. Thus, management of SSFs with harvest controls alone will be ineffective if these environmentally driven variations in abundance and habitat quality are not taken into account (Caddy 2007). An appropriate exploitation strategy seems to be to harvest sink areas, with populations made up of one or two year classes, but avoiding overexploiting the "core or source," which could be identified by the presence of multiple year classes that survived previous anomalous climatic episodes (Caddy and Defeo 2003). These source areas should be closed to fishing during favorable years that could include El Niño events (see Fig. 3B, D), to trigger the recovery of the stocks. However, there are no examples in which the "sourcesink" metapopulation theory has been applied to manage Latin American shellfisheries in the context of climate variability. Solid SSF management should also be able to recognize earlywarning signals of climate tipping points (Scheffer et al. 2009, Lenton 2011) before populations go into rapid decline. As overfishing reduces resilience of stocks to climate-driven catastrophic phase shifts (Ling et al. 2009), detection capabilities of early-warning signals previous to such shifts are of critical importance. However, the detection of these signals remains a challenge because (Boettiger and Hastings 2013): (1) vast amounts of data should be collected well before the system nears a tipping point; and (2) long-term trends could be subject to undocumented changes in data-collection procedures, a switch in management practice, or a shift in environmental conditions.

The recognition of spatial patterns in population demography and dynamics is of utmost importance for marine spatial planning and management of stocks exploited by SSFs in Latin America (Defeo and Castilla 2005, Castrejón and Charles 2013). In this context, matching spatial property rights and size of the management units with scales of dispersal is urgently needed to achieve management success (Castilla and Defeo 2001, McCay and Jones 2011, White and Costello 2011). If this requirement is fulfilled, a combination of spatially-oriented tools that include spatial property rights (TURFs) and Marine Protected Areas (MPAs) strategically sited could increase both fishery profits and abundance (Costello and Kaffine 2010) and, at the same time, could respond more effectively to climate change (McCay and Jones 2011). These tools could be complemented by cooperation arrangements and quota regulations (Gutiérrez et al. 2011, White and Costello 2011) and, if strategically sited and distributed, could ameliorate ecosystem impacts caused by increasing SSTA associated with global warming (Edgar et al. 2010). Micheli et al. (2012) showed that, despite high and widespread mass mortality events of benthic invertebrates in Baja California, Mexico, juvenile replenishment of the pink abalone (Haliotis corrugata) remained stable within MPAs, because of large body size and high egg production of the protected adults.

A species' vulnerability to climate change depends on its exposure and sensitivity to climate variability, its resilience to recover from perturbations, and its potential to adapt to change (Williams et al. 2008). These vulnerability criteria require behavioral, physiological, and genetic data (Doney et al. 2012, 
Huey et al. 2012), which is needed for species targeted by SSFs in Latin America. This is particularly important for coastal shellfisheries, where exploitation is increasingly constrained by the accumulation of toxins associated to harmful algal blooms, which can render them unsafe for human consumption (Defeo et al. 2009). The budget for realtime monitoring, control, and surveillance of these events is insufficient in Latin American countries, and the risk of diseases for consumers is high. Vulnerability assessment to climate change requires a multidisciplinary effort to develop adaptive management frameworks directed to mitigate the effects of climatic drivers on species and on coastal communities' well-being. Decision-making processes on SSFs should also focus on implementing adaptation responses to cope with potential bioeconomic losses (Grafton 2010, Cinner et al. 2012a), such as the reduction in the number of fishing days and economic revenues resulting from habitat loss (see Fig. 2).

Weak governance, e.g., open access, and a problematic governability, i.e., governance capacity, have exacerbated climate-induced changes on SSFs in Latin America. Both issues represent major threats to the social security of Latin American fishers (Kalikoski et al. 2010, Defeo and Castilla 2012). Governance institutions (sensu Chuenpagdee and Song 2012) have been unable to adopt proactive and effective governing actions to deal with the combined impact of fishing and climate variability on communities' well-being. Weak governance, in conjunction with erosion of traditional resource use systems, open-access regimes, poverty, lack of alternative employment, and easy access to stocks with low investment and operating costs, has promoted overfishing and increased the vulnerability of SSF communities to climate change in Latin America (Kalikoski et al. 2010). Defeo and Castilla (2012) recently categorized the issues highlighted above as "wicked fishery problems" (sensu Jentoft and Chuenpagdee 2009) that undermine SSF governance systems. Some localscale solutions to these governance and governability problems include self-imposed governance with spatial property rights, internal rules, and comanagement (Basurto 2005, Defeo and Castilla 2005, 2012, Gelcich et al. 2010). Adaptive comanagement in self-organized communities is able to create ways to develop mechanisms to cope with the influence of climate variability on resource abundance and availability (Kalikoski et al. 2010), promoting flexible adaptation responses and strengthening adaptive capacities to different drivers (Grafton 2010, Cinner et al. 2012a). Finally, ecolabelling programs created additional incentives for improved management systems and stronger governance structures (Gutiérrez et al. 2012). For example, the Baja California rock lobster Marine Stewardship Council (MSC) certification empowered cooperatives, promoting their autonomy and ultimately improving the resilience of the system (Pérez-Ramírez et al. 2012).
At larger scales, sea-zoning for artisanal and industrial fleets, including allocation of exclusive spatial rights to SSF communities, mitigated governance problems in some countries, including Chile (Castilla 2010) and Uruguay (Horta and Defeo 2012). However, local institutions generally lack cross-scale linkages with higher governance levels (Cinner et al. 2012b), suggesting that formal cross-scale governance recognition and support through the institutionalization of fishery rights is still needed in Latin American SSFs (Defeo and Castilla 2005, Chakalall et al. 2007). This is of the utmost importance in highly valued transboundary resources, e.g., spiny lobsters, which require regional institutional arrangements to be properly managed in Latin America.

Unit price constitutes a key economic driver that could lead to stock depletion in Latin American SSFs (reviewed in Defeo and Castilla 2012). Deficit of supply relative to an exponentially growing demand, associated with high export prices, triggered an increase in fishing effort, which in turn affected stock sustainability. This phenomenon is particularly noticeable in coastal SSFs, because price values of the exploited species largely exceed the low investment and operating costs. In addition, illegal trade accelerated depletion rates, taking advantage of the high intertemporal preferences in resource use and the inadequate enforcement of management measures (Defeo and Castilla 2012). This highlights the need to develop solid governance fishery systems by the consolidation of strong institutions that promote resilience under uncertainty scenarios of biophysical and social issues (Gutiérrez et al. 2011). Therefore, to cope with the increasing uncertainty on the long-term impact of climate change and globalization of international markets, we urgently need solid institutions, better governance systems, and effective management regulations to ensure successful, safe, and sustainable SSFs in Latin America.

Responses to this article can be read online at: http://www.ecologyandsociety.org/issues/responses. php/5971

\section{Acknowledgments:}

We are grateful for the financial support provided by The Pew Fellows Program in Marine Conservation (OD and JCC), DINARA's UTF and GEF projects (OD and LO), ICM, Ministerio de Economía, Fomento y Turismo, Chile (JCC), World Wildlife Funds' Russell E. Train Education for Nature Program, NSERC Canada and CONACYT Mexico (MC) and SENESCYT Ecuador (AK). MC and AK acknowledge the Galapagos National Park and the Charles Darwin Foundation for sharing the shellfish catch and SST time series from Galapagos. This document contains sections of the PhD thesis of $L O$. 


\section{LITERATURE CITED}

Acha, E. M., C. G. Simionato, C. Carozza, and H. Mianzán. 2012. Climate-induced year-class fluctuations of whitemouth croaker Micropogonias furnieri (Pisces, Sciaenidae) in the Río de la Plata estuary, Argentina-Uruguay. Fisheries Oceanography 21:58-77.

Arntz, W. E., T. Brey, J. Tarazona, and A. Robles. 1987. Changes in the structure of a shallow sandy-beach community in Peru during an El Niño event. Pages 645-658 in A. I. Payne, J. A. Gulland, and K. H. Bink, editors. The Benguela and comparable ecosystems. South African Journal of Marine Science 5.

Badjeck, M. C., J. Mendo, M. Wolff, and H. Lange. 2009. Climate variability and the Peruvian scallop fishery: the role of formal institutions in resilience building. Climatic Change 94:211-232. http://dx.doi.org/10.1007/s10584-009-9545-y

Barange, M., W. W. L. Cheung, G. Merino, and R. I. Perry. 2010. Modelling the potential impacts of climate change and human activities on the sustainability of marine resources. Current Opinion in Environmental Sustainability 2:326-333. http://dx.doi.org/10.1016/j.cosust.2010.10.002

Basurto, X. 2005. How locally designed access and use controls can prevent the tragedy of the commons in a Mexican small-scale fishing community. Society \& Natural Resources 18:643-659. http://dx.doi.org/10.1080/08941920590959631

Begossi, A. 2010. Small-scale fisheries in Latin America: management models and challenges. Maritime Studies 9:7-31.

Berkes, F., R. Mahon, P. McConney, R. Pollnac, and R. Pomeroy. 2001. Managing small-scale fisheries. Alternative directions and methods. International Development Research Centre, Ottawa, Ontario, Canada.

Blanco, J. A., J. C. N. Barandica, and E. A. Viloria. 2007. ENSO and the rise and fall of a tilapia fishery in northern Colombia. Fisheries Research 88:100-108. http://dx.doi. org/10.1016/j.fishres.2007.07.015

Boettiger, C., and A. Hastings. 2013. From patterns to predictions. Nature 493:157-158.

Bovarnick, A., F. Alpizar, C. Schnell, editors. 2010. The importance of biodiversity and ecosystems in economic growth and equity in Latin America and the Caribbean: an economic valuation of ecosystems. United Nations Development Programme, New York, New York, USA.

Bueno, N., and X. Basurto. 2009. Resilience and collapse of artisanal fisheries: a system dynamics analysis of a shellfish fishery in the Gulf of California, Mexico. Sustainability Science 4:139-149. http://dx.doi.org/10.1007/s11625-009-0087$\underline{\mathrm{Z}}$
Bustamante, R. H., G. M. Branch, R. Bensted-Smith, and G. J. Edgar. 2002. The status of and threats to marine biodiversity. Pages 80-95 in R. Bensted-Smith, editor. A biodiversity vision for the Galapagos Islands. Charles Darwin Foundation and World Wildlife Fund, Galapagos, Ecuador.

Caddy, J. F. 2007. Marine habitat and cover: their importance for productive coastal fishery resources. UNESCO Publishing, Paris, France

Caddy, J. F., and O. Defeo. 2003. Enhancing or restoring the productivity of natural populations of shellfish and other marine invertebrate resources. FAO Fisheries Technical Paper No. 448, Food and Agriculture Organization, Rome, Italy.

Castilla, J. C. 2010. Fisheries in Chile: small pelagics, management, rights, and sea zoning. Bulletin of Marine Science 86:221-234.

Castilla, J. C., and P. A. Camus. 1992. The Humboldt El Niño scenario: coastal benthic resources and anthropogenic influences, with particular reference to the 1982/83 ENSO. South African Journal of Marine Science 12:703-712. http:// dx.doi.org/10.2989/02577619209504735

Castilla, J. C., and O. Defeo. 2001. Latin-American benthic shellfisheries: emphasis on co-management and experimental practices. Reviews in Fish Biology and Fisheries 11:1-30. http://dx.doi.org/10.1023/A:1014235924952

Castilla, J. C., and P. E. Neill. 2009. Marine bioinvasions in the Southeastern Pacific: status, ecology, economic impacts, conservation and management. Pages 439-457 in G. Rilov and J. A. Crooks, editors. Biological invasions in marine ecosystems. Ecological Studies 204, Springer-Verlag, Berlin, Germany. http://dx.doi.org/10.1007/978-3-540-79236-9 26

Castilla, J. C., M. Uribe, N. Bahamonde, M. Clarke, R. Desqueyroux-Faúndez, I. Kong, H. Moyano, N. Rozbaczylo, B. Santelices, C. Valdovinos, and P. Zavala. 2005. Down under the southeastern Pacific: marine non-indigenous species in Chile. Biological Invasions 7:213-232. http://dx.doi. org/10.1007/s10530-004-0198-5

Castrejón, M. 2011. Co-manejo pesquero en la Reserva Marina de Galápagos: tendencias, retos y perspectivas de cambio. Fundación Charles Darwin and Kanankil/Plaza Valdés, México.

Castrejón, M., and T. Charles. 2013. Improving fisheries comanagement through ecosystem-based spatial management: the Galapagos Marine Reserve. Marine Policy 38:235-245. http://dx.doi.org/10.1016/j.marpol.2012.05.040

Charles Darwin Foundation. 2012. CDF Meteorological Database. Online data portal. Charles Darwin Foundation, Galapagos, Ecuador. [online] URL: http://www.darwinfoundation. org/datazone/climate/ 
Chakalall, B., R. Mahon, P. McConney, L. Nurse, and D. Oderson. 2007. Governance of fisheries and other living marine resources in the Wider Caribbean. Fisheries Research 87:92-99. http://dx.doi.org/10.1016/j.fishres.2007.06.009

Chavez, F. P., J. Ryan, S. E. Lluch-Cota, and C. M. Ñiquen. 2003. From anchovies to sardines and back: multidecadal change in the Pacific Ocean. Science 299:217-221. http://dx. doi.org/10.1126/science.1075880

Cheung, W. W. L., R. Watson, and D. Pauly. 2013. Signature of ocean warming in global fisheries catch. Nature 497:365-368. http://dx.doi.org/10.1038/nature12156

Chuenpagdee, R., L. Liguori, M. L. D. Palomares, and D. Pauly. 2006. Bottom-up, global estimates of small-scale fisheries catches. Fisheries Centre Research Report 14, Vancouver, British Columbia, Canada.

Chuenpagdee, R., and A. M. Song 2012. Institutional thinking in fisheries governance: broadening perspectives. Current Opinion in Environmental Sustainability 4:309-315. http://dx. doi.org/10.1016/j.cosust.2012.05.006

Cinner, J. E., X. Basurto, P. Fidelman, J. Kuange, R. Lahari, and A. Mukminin. 2012b. Institutional designs of customary fisheries management arrangements in Indonesia, Papua New Guinea, and Mexico. Marine Policy 36:278-285. http://dx.doi. org/10.1016/j.marpol.2011.06.005

Cinner, J. E., T. R. McClanahan, N. A. J. Graham, T. M. Daw, J. Maina, S. M. Stead, A. Wamukota, K. Brown, and O. Bodin. 2012a. Vulnerability of coastal communities to key impacts of climate change on coral reef fisheries. Global Environmental Change 22:12-20. http://dx.doi.org/10.1016/j. gloenvcha.2011.09.018

Costello, C., and D. T. Kaffine. 2010. Marine protected areas in spatial property-rights fisheries. Australian Journal of Agricultural and Resource Economics 54:321-341. http://dx. doi.org/10.1111/j.1467-8489.2010.00495.x

Courchamp, F., E. Angulo, P. Rivalan, R. Hall, L. Signoret, L. Bull, and Y. Meinard. 2006. Rarity value and species extinction: the anthropogenic Allee effect. PLoS Biology 4: e415. http://dx.doi.org/10.1371/journal.pbio.0040415

Defeo, O. 2003. Marine invertebrate fisheries in sandy beaches: an overview. Journal of Coastal Research Special Issue 35:56-65.

Defeo, O., and J. C. Castilla. 1998. Harvesting and economic patterns in the artisanal Octopus mimus (Cephalopoda) fishery in a northern Chile cove. Fisheries Research 38:121-130. http://dx.doi.org/10.1016/S0165-7836(98)00155-6

Defeo, O., and J. C. Castilla. 2005. More than one bag for the world fishery crisis and keys for co-management successes in selected artisanal Latin American shellfisheries. Reviews in
Fish Biology and Fisheries 15:265-283. http://dx.doi. org/10.1007/s11160-005-4865-0

Defeo, O., and J. C. Castilla. 2012. Governance and governability of coastal shellfisheries in Latin America and the Caribbean: multi-scale emerging models and effects of globalization and climate change. Current Opinion in Environmental Sustainability 4:344-350. http://dx.doi. org/10.1016/j.cosust.2012.05.002

Defeo, O., and A. McLachlan. 2011. Coupling between macrofauna community structure and beach type: a deconstructive meta-analysis. Marine Ecology Progress Series 433:29-41. http://dx.doi.org/10.3354/meps09206

Defeo, O., A. McLachlan, D. S. Schoeman, T. Schlacher, J. Dugan, A. Jones, M. Lastra, and F. Scapini. 2009. Threats to sandy beach ecosystems: a review. Estuarine, Coastal and Shelf Science 81:1-12. http://dx.doi.org/10.1016/j.ecss.2008.09.022

Delworth, T. L., and M. E. Mann. 2000. Observed and simulated multidecadal variability in the Northern Hemisphere. Climate Dynamics 16:661-676. http://dx.doi. org $/ 10.1007 / \mathrm{s} 003820000075$

Doney, S. C., M. Ruckelshaus, J. E. Duffy, J. P. Barry, F. Chan, C. A. English, H. M. Galindo, J. M. Grebmeier, A. B. Hollowed, N. Knowlton, J. Polovina, N. N. Rabalais, W. J. Sydeman, and L. D. Talley. 2012. Climate change impacts on marine ecosystems. Annual Review of Marine Science 4:11-37. http://dx.doi.org/10.1146/annurev-marine-041911-111611

Edgar, G. J., S. A. Banks, M. Brandt, R. H. Bustamante, A. Chiriboga, S. A. Earle, L. E. Garske, P. W. Glynn, J. S. Grove, S. Henderson, C. P. Hickman, K. A. Miller, F. Rivera, and G. M. Wellington. 2010. El Niño, grazers and fisheries interact to greatly elevate extinction risk for Galapagos marine species. Global Change Biology 16:2876-2890. http://dx.doi. org/10.1111/j.1365-2486.2009.02117.x

Ficke, A. D., C. A. Myrick, and L. J. Hansen. 2007. Potential impacts of global climate change on freshwater fisheries. Reviews in Fish Biology and Fisheries 17:581-613. http://dx. doi.org/10.1007/s11160-007-9059-5

Fiedler, P. C. 2002. Environmental change in the eastern tropical Pacific Ocean: review of ENSO and decadal variability. Marine Ecology Progress Series 244:265-283. http://dx.doi.org/10.3354/meps244265

Fiori, S., and O. Defeo. 2006. Biogeographic patterns in lifehistory traits of the yellow clam, Mesodesma mactroides, in sandy beaches of South America. Journal of Coastal Research 22:872-880. http://dx.doi.org/10.2112/04-0409.1

Fiori, S., V. Vidal-Martínez, R. Simá-Álvarez, R. RodríguezCanul, M. L. Aguirre-Macedo, and O. Defeo. 2004. Field and laboratory observations of the mass mortality of the yellow clam Mesodesma mactroides in South America: the case of 
Isla del Jabalí, Argentina. Journal of Shellfish Research 23:451-455.

Folke, C., A. Jansson, J. Rockström, P. Olsson, S. R. Carpenter, S. F. Chapin III, A.-S. Crépin, G. Daily, G. Danell, J. Ebbesson, T. Elmqvist, V. Galaz, F. Moberg, M. Nilsson, H. Österblom, E. Ostrom, Å. Persson, G. Peterson, S. Polasky, W. Steffen, B. Walker, and F. Westley. 2011. Reconnecting to the biosphere. Ambio 40:719-738. http://dx.doi. org/10.1007/s13280-011-0184-y

Food and Agriculture Organization (FAO). 2012. Report of the Workshop on International Guidelines for Securing Sustainable Small-Scale Fisheries. FAO Fisheries and Aquaculture Report No 1004. FAO, Rome, Italy.

Gelcich, S., T. Hughes, P. Olsson, C. Folke, O. Defeo, M. Fernández, S. Foale, L. Gunderson, C. Rodríguez-Sickert, M. Scheffer, R. S. Steneck, and J. C. Castilla. 2010. Navigating transformations in governance of Chilean marine coastal resources. Proceedings of the National Academy of Sciences of the United States of America 107:16794-16799. http://dx. doi.org/10.1073/pnas.1012021107

Goldenberg, S. B., C. W. Landsea, A. M. Mestas-Nuñez, and W. M. Gray. 2001. The recent increase in Atlantic hurricane activity: causes and implications. Science 293:474-479. http:// dx.doi.org/10.1126/science. 1060040

Grafton, R. Q. 2010. Adaptation to climate change in marine capture fisheries. Marine Policy 34:606-615. http://dx.doi. org/10.1016/j.marpol.2009.11.011

Gutiérrez, N. L., R. Hilborn, and O. Defeo. 2011. Leadership, social capital and incentives promote successful fisheries. Nature 470:386-389. http://dx.doi.org/10.1038/nature09689

Gutiérrez, N. L., S. R. Valencia, T. A. Branch, D. J. Agnew, J. K. Baumd, P. L. Bianchi, J. Cornejo-Donoso, C. Costello, O. Defeo, T. E. Essington, Ray Hilborn, D. D. Hoggarth, A. E. Larsen, C. Ninnes, K. Sainsbury, R. L. Selden, S. Sistla, A. D. M. Smith, A. Stern-Pirlot, S. J. Teck, J. T. Thorson, and N. E. Williams 2012. Eco-label conveys reliable information on fish stock health to seafood consumers. PLoS ONE 7(8): e43765. http://dx.doi.org/10.1371/journal.pone.0043765

Hall, S. J. 2011. Climate change and other external drivers in small-scale fisheries: practical steps for responding. Pages 132-159 in R. S. Pomeroy and N. L. Andrew, editors. Smallscale fisheries management: frameworks and approaches for the developing world. CAB International, Cambridge, UK.

Hearn, A., P. Martínez, M. V. Toral-Granda, J. C. Murillo, and J. Polovina. 2005. Population dynamics of the exploited sea cucumber Isostichopus fuscus in the Western Galápagos Islands, Ecuador. Fisheries Oceanography 14:377-385. http://dx.doi.org/10.1111/j.1365-2419.2005.00342.x
Hearn A., and J. C. Murillo. 2008. Life history of the red spiny lobster, Panulirus penicillatus (Decapoda: Palinuridae), in the Galápagos Marine Reserve, Ecuador. Pacific Science 62:191-204. http://dx.doi.org/10.2984/1534-6188(2008)62 [191:LHOTRS]2.0.CO;2

Heath, M. R., F. C. Neat, J. K. Pinnegar, D. G. Reid, D. W. Sims, and P. J. Wright. 2012. Review of climate change impacts on marine fish and shellfish around the UK and Ireland. Aquatic Conservation: Marine and Freshwater Ecosystems 22:337-367. http://dx.doi.org/10.1002/aqc.2244

Herrmann, M., J. Alfaya, M. Lepore, P. Penchaszadeh, and W. Arntz. 2011. Population structure, growth and production of the yellow clam Mesodesma mactroides (Bivalvia: Mesodesmatidae) from a high-energy, temperate beach in northern Argentina. Helgoland Marine Research 65:285-297. http://dx.doi.org/10.1007/s10152-010-0222-3

Horta, S., and O. Defeo. 2012. The spatial dynamics of the whitemouth croaker artisanal fishery in Uruguay and interdependencies with the industrial fleet. Fisheries Research 125-126:121-128. http://dx.doi.org/10.1016/j.fishres.2012.02.007

Huey, R. B., M. R. Kearney, A. Krockenberger, J. A. M. Holtum, M. Jess, and S. E. Williams. 2012. Predicting organismal vulnerability to climate warming: roles of behaviour, physiology and adaptation. Philosophical Transactions of the Royal Society B 367:1665-1679. http://dx. doi.org/10.1098/rstb.2012.0005

Intergovernmental Panel on Climate Change (IPCC). 2007. Climate change 2007: synthesis report. Core Writing Team, R. K. Pachauri, and A. Reisinger, editors. Contribution of Working Groups I, II and III to the Fourth Assessment Report of the Intergovernmental Panel on Climate Change Core Writing Team. IPCC, Geneva, Switzerland.

Jentoft, S., and R. Chuenpagdee. 2009. Fisheries and coastal governance as a wicked problem. Marine Policy 33:553-560. http://dx.doi.org/10.1016/j.marpol.2008.12.002

Jentoft, S., and A. Eide, editors. 2011. Poverty mosaics: realities and prospects in small-scale fisheries. Springer, Berlin, Germany. http://dx.doi.org/10.1007/978-94-007-1582-0

Jeppesen, E., T. Mehner, I. J. Winfield, K. Kangur, J. Sarvala, D. Gerdeaux, M. Rask, H. J. Malmquist, K. Holmgren, P. Volta, S. Romo, R. Eckmann, A. Sandström, S. Blanco, A. Kangur, H. R. Stabo, M. Tarvainen, A.-M. Ventelä, M. Søndergaard, T.L.Lauridsen, and M. Meerhoff. 2012. Impacts of climate warming on the long-term dynamics of key fish species in 24 European lakes. Hydrobiologia 694:1-39. http:// dx.doi.org/10.1007/s10750-012-1182-1

Kalikoski, D. C., P. Q. Neto, and T. Almudi. 2010. Building adaptive capacity to climate variability: the case of artisanal 
fisheries in the estuary of the Patos Lagoon, Brazil. Marine Policy 34:742-751. http://dx.doi.org/10.1016/j.marpol.2010.02.003

Lee, T., and M. J. McPhaden. 2010. Increasing intensity of El Niño in the central equatorial Pacific. Geophysical Research Letters 37:L14603. http://dx.doi.org/10.1029/2010GL044007

Lenton, T. M. 2011. Early warning of climate tipping points. Nature Climate Change 1:201-209. http://dx.doi.org/10.1038/ nclimate1143

Lercari, D., and L. Bergamino. 2011. Impacts of two invasive mollusks, Rapana venosa (Gastropoda) and Corbicula fluminea (Bivalvia), on the food web structure of the Río de la Plata estuary and nearshore oceanic ecosystem. Biological Invasions 13:2053-2061. http://dx.doi.org/10.1007/s10530-011-0023$\underline{\mathrm{X}}$

Ling, S. D., C. R. Johnson, S. D. Frusher, and K. R. Ridgway. 2009. Overfishing reduces resilience of kelp beds to climatedriven catastrophic phase shift. Proceedings of the National Academy of Sciences of the United States of America 106:22341-22345. http://dx.doi.org/10.1073/pnas.0907529106

Lluch-Cota, S. E., E. A. Aragón-Noriega, F. ArreguínSanchez, D. Aurioles-Gamboa, J. J. Bautista-Romero, R. C. Brusca, R. Cervantes-Duarte, R. Cortes-Altamirano, et al. 2007. The Gulf of California: review of ecosystem status and sustainability challenges. Progress in Oceanography 73:1-26. http://dx.doi.org/10.1016/j.pocean.2007.01.013

McCay, B. J., S. Brandt, and C. F. Creed. 2011. Human dimensions of climate change and fisheries in a coupled system: the Atlantic surfclam case. ICES Journal of Marine Science 68:1354-1367. http://dx.doi.org/10.1093/icesjms/ $\underline{\mathrm{fsr} 044}$

McCay, B. J., and P. J. S. Jones. 2011. Marine protected areas and the governance of marine ecosystems and fisheries. Conservation Biology 25:1130-1133. http://dx.doi.org/10.1111/ j.1523-1739.2011.01771.x

McLachlan, A., J. Dugan, O. Defeo, A. D. Ansell, D. M. Hubbard, E. Jaramillo, and P. E. Penchaszadeh. 1996. Beach clam fisheries. Oceanography and Marine Biology: AnAnnual Review 34:163-232.

Mellin, C., B. D. Russell, S. D. Connell, B. W. Brook, and D. A. Fordham. 2012. Geographic range determinants of two commercially important marine molluscs. Diversity and Distributions 18:133-146. http://dx.doi.org/10.1111/ j.1472-4642.2011.00822.x

Micheli, F., A. S. Saenz-Arroyo, A. Greenley, L. Vazquez, J. A. Espinoza-Montes, M. Rossetto, G. A. De Leo. 2012. Evidence that marine reserves enhance resilience to climatic impacts. PloS ONE 7:e40832. http://dx.doi.org/10.1371/ journal.pone.0040832
Montecino, V., and C. B. Lange. 2009. The Humboldt current system: ecosystem components and processes, fisheries, and sediment studies. Progress in Oceanography 83:65-79. http:// dx.doi.org/10.1016/j.pocean.2009.07.041

Murillo, J. C., P. Martínez, M. V. Toral-Granda, and A. Hearn. 2002. Pepino de Mar. Pages 176-197 in E. Danulat and G. Edgar, editors. Línea Base de la Biodiversidad. Fundación Charles Darwin y Servicio Parque Nacional Galápagos, Galápagos, Ecuador.

Narita, D., K. Rehdanz, and R. S. J. Tol. 2012. Economic costs of ocean acidification: a look into the impacts on global shellfish production. Climatic Change 113:1049-1063. http:// dx.doi.org/10.1007/s10584-011-0383-3

Orensanz, J. M., E. Schwindt, G. Pastorino, A. Bortolus, G. Casas, G. Darrigran, R. Elías, J. López-Gappa, S. Obenat, M. Pascual, P. Penchaszadeh, M. Piriz, F. Scarabino, E. Spivak, and E. Vallarino. 2002. No longer the pristine confines of the world ocean: a survey of exotic marine species in the southwestern Atlantic. Biological Invasions 4:115-143. http:// dx.doi.org/10.1023/A:1020596916153

Ortega, L., J. C. Castilla, M. Espino, C. Yamashiro, and O. Defeo. 2012 Effects of fishing, market price and climate on two South American clam species. Marine Ecology Progress Series 469:71-85. http://dx.doi.org/10.3354/meps10016

Ortega, L., E. Celentano, C. Finkl, and O. Defeo. 2013. Effects of climate variability on the morphodynamics of Uruguayan sandy beaches. Journal of Coastal Research 29:747-755. http://dx.doi.org/10.2112/JCOASTRES-D-13-00003.1

Ostrom, E. 2009. A general framework for analyzing sustainability of social-ecological systems. Science 325:419-422. http://dx.doi.org/10.1126/science.1172133

Pauly, D. 2006. Major trends in small-scale marine fisheries, with emphasis on developing countries, and some implications for the social sciences. Maritime Studies 4:7-22.

Pérez-Ramírez, M., G. Ponce-Díaz, and S. Lluch-Cota. 2012. The role of MSC certification in the empowerment of fishing cooperatives in Mexico: the case of red rock lobster comanaged fishery. Ocean \& Coastal Management 63:24-29. http://dx.doi.org/10.1016/j.ocecoaman.2012.03.009

Perry, R. I., R. E. Ommer, M. Barange, S. Jentoft, B. Neis, and U. R. Sumaila. 2011. Marine social-ecological responses to environmental change and the impacts of globalization. Fish and Fisheries 12:427-450. http://dx.doi.org/10.1111/ j.1467-2979.2010.00402.x

Perry, R. I., R. E. Ommer, M. Barange, and F. Werner. 2010. The challenge of adapting marine social-ecological systems to the additional stress of climate change. Current Opinion in Environmental Sustainability 2:356-363. http://dx.doi. org/10.1016/j.cosust.2010.10.004 
Revell, D. L., J. E. Dugan, and D. M. Hubbard. 2011. Physical and ecological responses of sandy beaches to the 1997-98 El Niño. Journal of Coastal Research 27:718-730. http://dx.doi. org/10.2112/JCOASTRES-D-09-00179.1

Riascos, J. M., D. Carstensen, J. Laudien, W. E. Arntz, M. E. Oliva, A. Güntner, and O. Heilmayer. 2009. Thriving and declining: climate variability shaping life-history and population persistence of Mesodesma donacium in the Humboldt Upwelling System. Marine Ecology Progress Series 385:151-163. http://dx.doi.org/10.3354/meps08042

Rouyer, T., J.-M. Fromentin, F. Ménard, B. Cazelles, K. Briand, R. Pianet, B. Planque, and N. C. Stenseth. 2008. Complex interplays among population dynamics, environmental forcing, and exploitation in fisheries. Proceedings of the National Academy of Sciences of the United States of America 105:5420-5425. http://dx.doi.org/10.1073/pnas.0709034105

Salas, S., R. Chuenpagdee, A. Charles, J. C. Seijo, editors. 2011. Coastal fisheries of Latin America and the Caribbean. FAO Fisheries and Aquaculture Technical Paper $\mathrm{N}^{\circ} 544$, Food and Agriculture Organization, Rome, Italy.

Scheffer, M., J. Bascompte, W. A. Brock, V. Brovkin, S. R. Carpenter, V. Dakos, H. Held, E. H. van Nes, M. Rietkerk, and G. Sugihara. 2009. Early-warning signals for critical transitions. Nature 461:53-59. http://dx.doi.org/10.1038/ $\underline{\text { nature } 08227}$

Stenseth, N. C., A. Mysterud, G. Ottersen, J. W. Hurrell, K.S. Chan, and M.o Lima. 2002. Ecological effects of climate fluctuations. Science 297:1292-1296. http://dx.doi.org/10.1126/ science. 1071281

Taylor, M. H., M. Wolff, J. Mendo, and C. Yamashiro. 2008. Changes in trophic flow structure of Independence Bay (Peru) over an ENSO cycle. Progress in Oceanography 79:336-351. http://dx.doi.org/10.1016/j.pocean.2008.10.006

White, C., and C. Costello. 2011. Matching spatial property rights fisheries with scales of fish dispersal. Ecological Applications 21:350-362. http://dx.doi.org/10.1890/09-1188.1

Williams, S. E., L. P. Shoo, J. L. Isaac, A. A. Hoffmann, and G. Langham. 2008. Towards an integrated framework for assessing the vulnerability of species to climate change. PLoS Biology 6:e325. http://dx.doi.org/10.1371/journal.pbio.0060325

Wolff, M., D. J. Ruiz, and M. Taylor. 2012a. El Niño induced changes to the Bolivar Channel ecosystem (Galapagos): comparing model simulations with historical biomass time series. Marine Ecology Progress Series 448:7-22. http://dx. doi.org/10.3354/meps09542

Wolff, M., A. Schubauer, and M. Castrejón. 2012b. A revised strategy for the monitoring and management of the Galapagos sea cucumber. International Journal of Tropical Biology 60:539-551. 